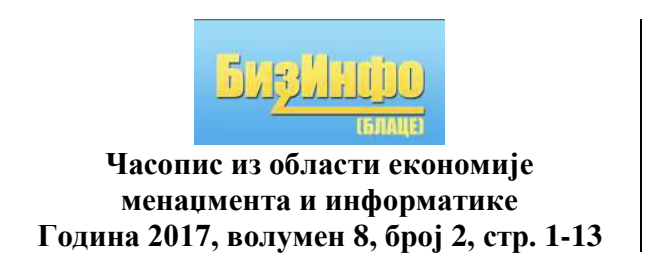

Година 2017, волумен 8, број 2, стр. 1-13

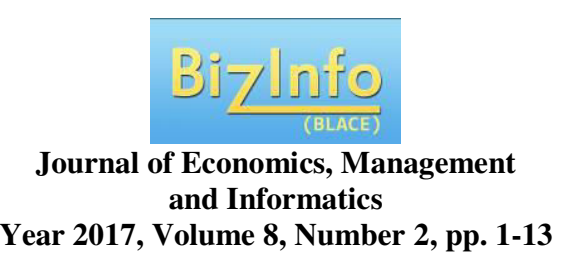

Прегледни рад/ Reviewing paper

УДК/UDC:

doi:10.5937/bizinfo1702001T

\title{
PRISONER DILEMMA BETWEEN POLICY MAKERS: EVIDENCE FROM TURKEY
}

\author{
Metin Tetik ${ }^{1}$ \\ Uşak University, School of Applied Science, Turkey \\ Reşat Ceylan ${ }^{2}$ \\ Pamukkale University, Department of Economics, Turkey
}

\begin{abstract}
In this study, we present about the interaction between monetary and fiscal policy makers in the Turkish economy since the 2001 crisis. This interaction is evaluated by a theoretical perspective of the game. The data show that there is a conflict between the monetary and fiscal policy makers in the Turkish economy, especially in some periods. The coordination problem created by this conflict is affecting social welfare negatively. Therefore, we argue that during these periods, there is a state of "Prisoners' Dilemma" among policy makers.
\end{abstract}

Key words: Monetary Policy, Fiscal Policy, Prisoners' Dilemma

\section{INTRODUCTION}

Traditionally, the formation of economic policies in macroeconomic policy theories is dealt with by policy makers. Macroeconomic policies are implemented by monetary and fiscal policy makers who have different goals and whose objectives are sometimes conflicting. This policy makers identifies and implements the optimal policy rule to shape the economy's structure and achieve its objectives. The politics of policy makers have different objectives and the conflict of these objectives make the optimal policy rules they are dependent on each other and macroeconomic policy affect the formation process.

\footnotetext{
${ }^{1}$ metin.tetik@usak.edu.tr

${ }^{2}$ rceylan@pau.edu.tr
} 
This process is modelled within the framework of game theory, as policy makers are in strategic interaction during the formation process of macroeconomic policies. In these models, policies take into account the mutual strategic interaction between policy makers. It is therefore treated as a player with individual goals, anticipations and preferences of policy makers within the framework of game theory. The game theoretical policy models, which have emerged as a result of the new political economy, have become a field of research that brought political and economic behavior together in the 1980s. Compared to the past, methods such as game theory and econometrics used by the new political economy approach have provided a better understanding and more detailed study of the interaction between economic and political behavior of economic agent (Telatar and Erdoğan, 1997).

The game between policy makers is aimed at the aims of policy makers and the means they will use to achieve these goals, the game is theoretically handled to move together (cooperation) or to move away from cooperation in the direction of individual objectives. In this respect, the problem of cooperation between policy makers is assessed through the influence of social welfare, mainly inflation, budget deficit and away from potential output.

\subsection{TWO INDEPENDENT POLICY MAKERS}

Monetary and fiscal policy makers are likely to have a tendency to develop policy preferences far from cooperation when looking at policy objectives. This is because, for example, from the perspective of the fiscal policy maker (government), voters' wishes lower tax rates and greater transfer expenditures, may provide the government with an expansionary policy if short-term inflation expectations are in line with expectations. The monetary policy maker considers that inflation is a bigger problem as the economy looks at it with a long-run view. Therefore, policy makers can adopt opposite policy choices (Blinder, 1982).

It is important to estimate the outcome of this situation when the game is theoretically covered by two independent policy makers within the framework of game theory. This game with two policy makers is treated as a non-zero game. The game solution is obtained by finding the Nash equilibrium. For Nash equilibrium, it is assumed that each policy maker is facing a rational competitor, so that each policy maker knows that the other will give the best response. In Figure 1, the game, pay-off matrices between two independent policy makers are represented. The value to the left of each box in the gain matrix shows the preference order of the monetary policy maker and the value to the right shows the preference order of the fiscal 
policy maker. ' 1 ' value ise the most preferred and ' 4 ' value represent the last preferred policy. Structure of this game resemble a prisoners dilemma.

\begin{tabular}{|c|c|c|c|}
\hline \multicolumn{4}{|c|}{ Fig. 1: Policy Maker's Pay-off Matrix } \\
\hline & & Expansion & Contraction \\
\hline \multirow[t]{2}{*}{ Monetary Policy } & Expansion & 4,1 & 2,2 \\
\hline & Contraction & 3,3 & 1,4 \\
\hline
\end{tabular}

Each policy maker has two strategies as expansion and contraction. Assuming that the fiscal policy maker prefers expansionary policies, the best thing for the fiscal policy maker in this case is that the monetary policy maker is also implementing a expansionary policies, and the worse thing is that the monetary policy maker is implementing a contractionary policies. The monetary policy maker, which is to fight inflation, supports the restrictive policies in the economy. Assuming that the monetary policy maker chose a restrictive policy, the best thing for the monetary policy maker in this case is that the fiscal policy maker is also implementing a contractionary policies and the worse thing is that the fiscal policy maker is implementing a expansionary policies. In this framework, expansionary policies for the fiscal policy maker are dominant, while contractionary policies for the monetary policy makers are dominant. Therefore, this game between policy makers is the definite dominant strategy equilibrium is (Contraction, Expansion) strategy profile. This is the Nash equilibrium of the game at the same time. The Nash equilibrium reflects the most reasonable behavior in the absence of coordination. However, as shown in the pay-off matrix, the right top box (Expansion, Contraction) has a better strategy profile than the Nash equilibrium. In the case of full coordination, it is assumed that policy makers will prefer this policy mix. Nash equilibrium represents the second best case when an coordination can not be reached.

In Nordhaus et al. (1994) study, analyzed the lack of coordination among policy makers. This study is shown, through reaction functions, that the Nash equilibrium shown in Figure 1 is not a blissful policy maker due to lack of coordination. 
Fig. 2: Reaction Functions in Non-cooperative Game

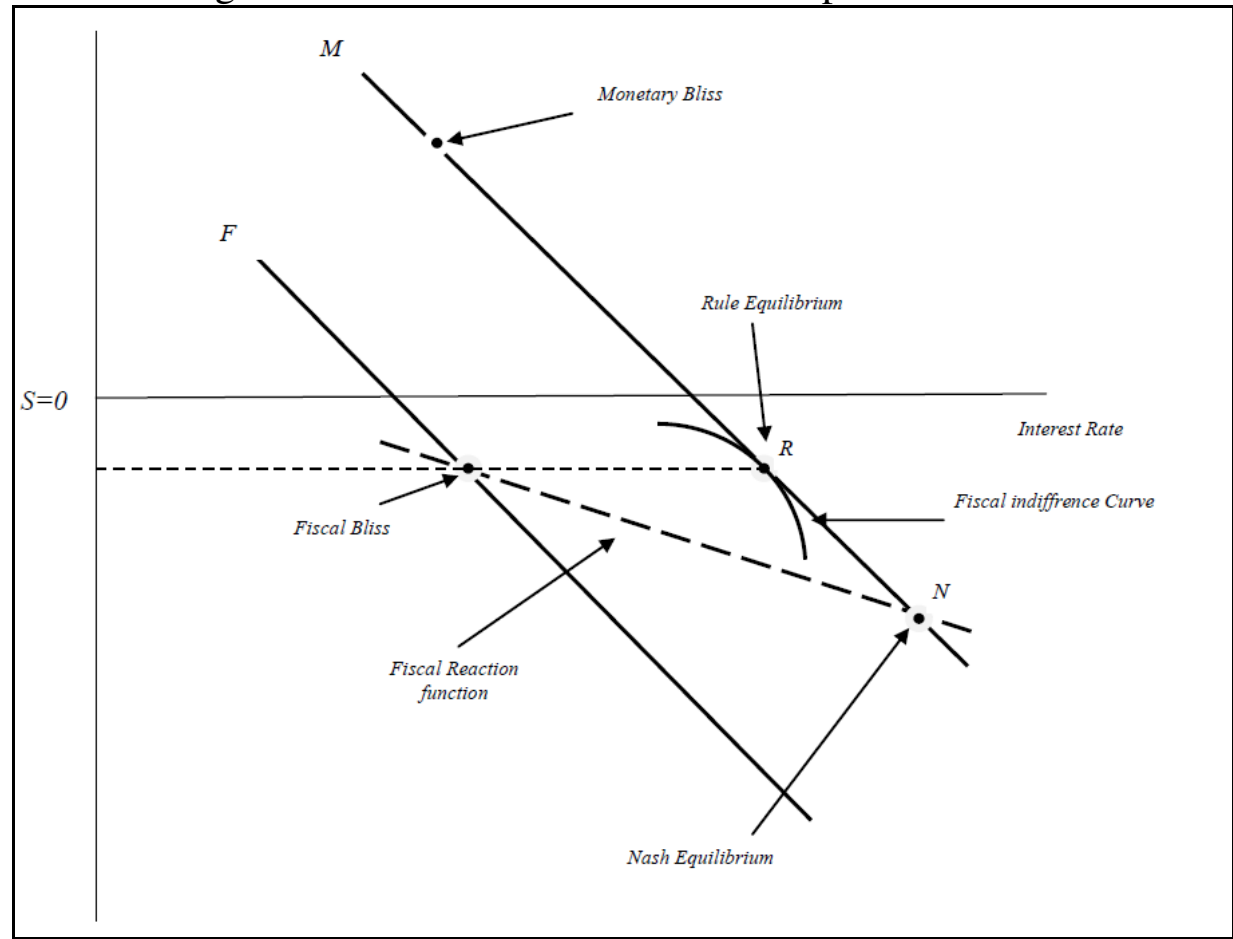

Source: Nordhaus, W.D. (1994) Policy Games: Co-ordination and Independence in Monetary and Fiscal Policies, Brooking Papers on Economic Activity 2: 150.

Figure 2 shows the reaction functions of both policy makers. The curve denoted by $\mathrm{M}$ is a consistent reaction function of the optimal monetary policy maker. F shows the optimal policy of the fiscal policy maker and the reaction function is shown in pieces. Nash equilibrium is at point $\mathrm{N}$ in the uncooperative vote, as can be understood from the figure. This is where both policy makers have high interest rates and budget deficits that they do not want. High interest and budget deficits will have a negative impact on output and inflation, two key factors that represent social welfare. Therefore, it can be said that this situation reflect the prisoners dilemma.

\section{THE VIEW OF THE TURKISH ECONOMY IN TERMS OF POLICY MAKERS}

It is known that the Turkish economy has gone through many macroeconomic developments such as liberal capital, export-led growth, and inflation targeting. In the pre-2000 period when the Turkish economy suffered large budget deficits, the current account deficit was also given. As a result of these problems, the debt burdens to which the commercial banks are not rationalized are added, and one of the most important crises of Turkish economic history emerged after 2000. It is known that some structural deficiencies of the Turkish economy have emerged with this crisis that took 
place in February 2001. A number of structural reforms have been undertaken since this date. Since February 22, 2001, the fixed exchange rate regime has been replaced by the floating exchange rate regime. Then it is thought that the comprehensive stabilization program implemented almost at the same time as the world is an important turning point for the Turkish economy. The stabilization program that is put into practice is about the regulation of monetary and fiscal policies and the banking system. In terms of fiscal policy, the government budget is under control with this stabilization program. When it is evaluated in terms of monetary policy, this policy maker, the Central Bank of the Republic of Turkey(CBRT), has now legally declared independence of means and purpose. It is also clearly stated that the main objective of the CBRT is to maintain price stability.

Another turning point in terms of economic policy is to remove the systemic risks due to the global financial crisis that took place in 2008 and which affects the whole world, thus leading to the creation of policies that will prevent the negativities in the financial system from affecting the economy as a whole. In order to focus their efforts on this, policy makers have pursued a strategy called "macro prudential policies". Macro prudential policy has been implemented because of the adverse conditions in the financial sector, the low growth rates created in the real economy, the serious deterioration in the government budget, and the possibility of monetary policy adversely affecting the ability to provide economic direction and price stability. Macro prudential policy strategy can be said to be an effective measure and regulation for the whole of the financial system to solve these problems. In the light of this information, it will be a better way to evaluate the interaction of the monetary and fiscal policy maker in the Turkish economy.

\subsection{FISCAL POLICY STANCE}

In order to evaluate the behavior of the fiscal policy maker in the Turkish economy, it is thought that the budget balance in this period is beneficial to look at the situation of government expenditures and tax revenues. 
Fig. 3: Fiscal Policy Stance
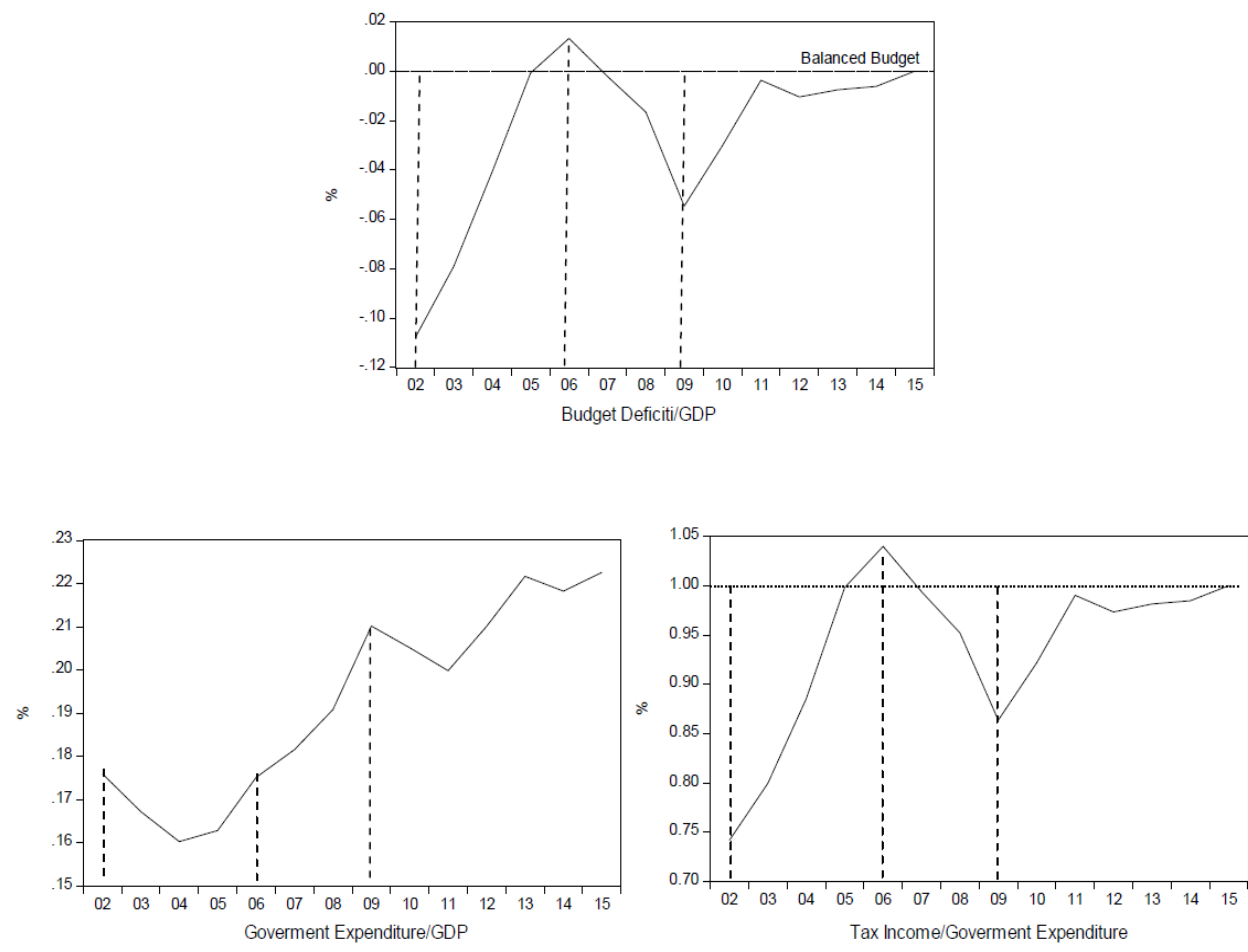

Source: Balance of budget government expenditures and tax revenues are provided from the Republic of Turkey Ministry of Undersecreteriat of Treasury databases.

As can be understood from Figure 3, it is observed that the budget deficit has declined rapidly in the post-2001 period. This situation is considered to be a necessary condition for the implementation of the stabilization program to move away from the twin deficits (budget deficit and current account deficit) cycle. This strong financial structure can be achieved as a result of the global financial crisis of 2009, which is an important factor in the short-lived recession in the Turkish economy. As a result of increased primary spending due to the fiscal policy maker's commitment to expanding to compensate for the decline in demand for the private sector in the global financial crisis, the budget deficit to GDP ratio in 2009 was $5.5 \%$, but this seems to be temporary. The temporary increase in the budget deficit can not be attributed to the fiscal policy maker's narrowing past, but on the contrary, from the government expenditure/ GDP figure that the fiscal policy maker continues to expand.

Government spending has increased steadily since 2006 , especially with the 2009 global financial crisis. Supporting aggregate demand can be attributed to increased government spending by boosting GDP growth and closing the output gap. However, expansionist stance is not caused by an increase in tax 
revenues as it is understood that it does not increase the budget deficit. This is thought to be mainly due to the interaction between monetary and fiscal policymakers. Increased government spending should be considered together with the CBRT's policy rate cuts in this period. This is also discussed in a sub-section on the stance of the monetary policy maker. The lowering of the CBRT's interest rates created a decline in the government's interest expenditures, followed by a slight increase in tax revenues, which affected the budget deficit positively. The 2009 global financial crisis has caused the fiscal policy maker to show an expanding stance. However, it is seen in Figure 3 that the fiscal policy maker does not give up its expansionist attitude despite the diminishing effect of the crisis on output.

\subsection{MONETARY POLICY STANCE}

The CBRT adopted the inflation targeting strategy by stating that it gained its independence in 2001 and its aim was to provide price stability. Has transformed its strategy of inflation targeting, which has been implicitly applied between 2002 and 2005, to open inflation targeting from 2006 onwards. It is seen in Figure 5 that the inflation rates in Turkey dropped from double-digit figures to single-digit figures together with the applied inflation targeting.

With the global crisis in 2009, it can be said that the expansionist policy implemented by the CBRT contributed to the recovery. However, due to the complex nature of the CBRT's policy actions (interest rate corridor, policy rate, etc.) it is difficult to measure how much it contributes to this recovery. It can be said that after 2010, the CBRT has moved away from its strategy of inflation targeting due to its focus on other economic problems such as current account deficit and capital inflows (Gürkaynak et al., 2015). Davig and Gürkaynak (2015) have shown that the monetary policy maker in trying to ineffectively use the appropriate tools of the fiscal policy maker to reduce this welfare level of trying to make this ineffectiveness. The situation in this period follows the definition given here.

The fact that the policy interest rate applied by the CBRT since 2010 has differed from the market interest rate means that the policy rate of the CBRT is actually an instrument that does not inform us about the monetary policy stance. As a matter of fact, the CBRT stated in the financial stability reports that the interbank money market interest rates will be higher than the policy interest rates. Due to this uncertainty, a different measure than the official policy rate is considered necessary for the policy stance of the CBRT.

Alp et al. (2010) point out that the one-week Turkish lira buying rate (TRlibor) is the instrument that has the power to the best predict the monetary 
policy decisions. Using this rate, CBRT's policy stance, and inflation rate which is target variable after 2006 is shown in Figure 4.

Fig. 4: Monetary Policy Stance

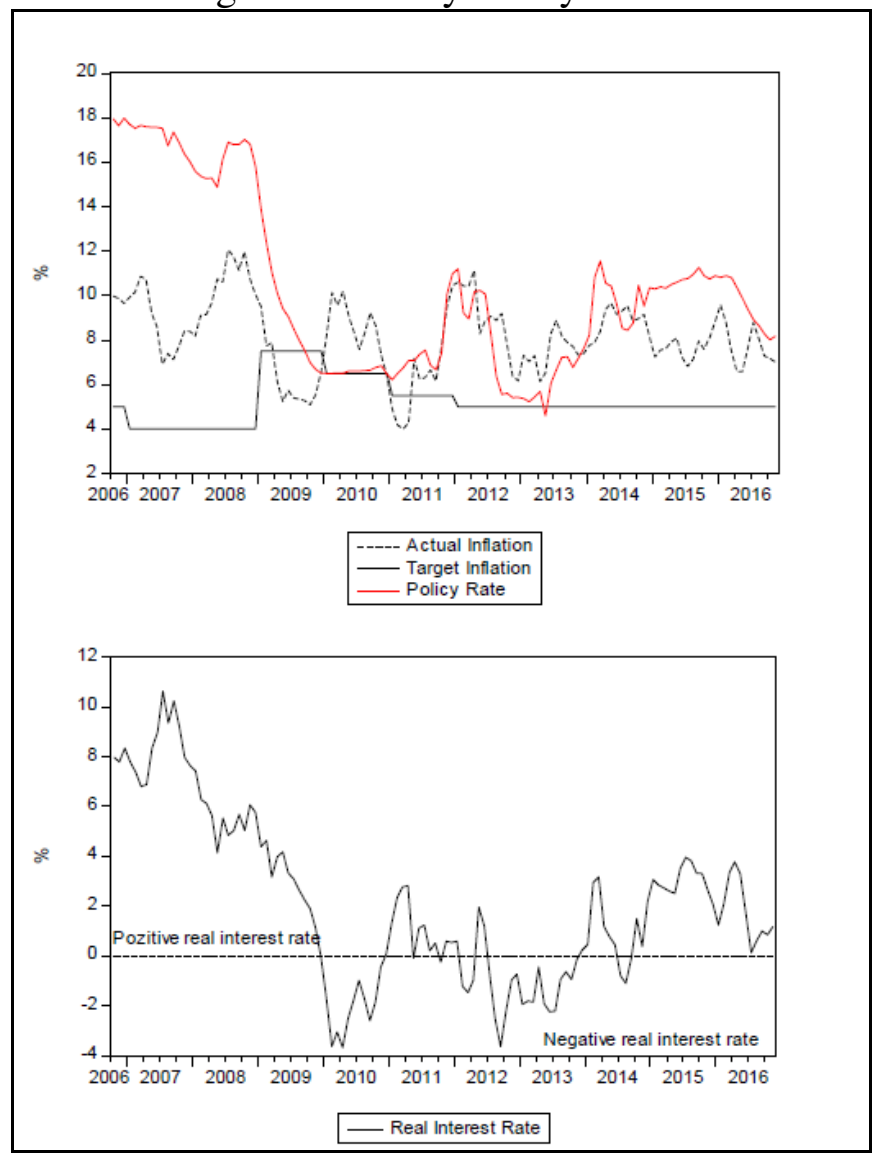

Source: The actual inflation rate and inflation target data are provided from the CBRT, and the policy interest rate (Trlibor) data is provided from the TBB databases.

As can be seen in Figure 4, the CBT gradually reduced its policy interest rates in the framework of inflation targeting from the year 2002 to the period 20062011. During the deepening global economic crisis in 2009, the CBRT cut its policy interest rates to the lowest levels in recent history as a monetary policy. Looking at Figure 4, negative real interest rates are seen in the Turkish economy during the global financial crisis1. In this period both the fiscal policy maker and the monetary policy maker are expanding. After 2010, the performance of the Turkish economy has increased steadily. An important indicator of monetary policy maker stance is the course of interest rates in 2012-2013. Although there has been no recession between these periods, it still appears to be expanding and negative real interest rate situation continues.

${ }^{1}$ See for details; CBRT (2009), "Inflation Report" 2009-IV 


\section{EVALUATION OF THE INTERACTION OF MONETARY AND FISCAL POLICIES IN TERMS OF SOCIAL WELFARE}

In the post-2001 period, macroeconomic variables representing social welfare are thought to be beneficial to create a framework of monetary and fiscal policy for Turkey. In this frame, Figure 5 shows the outlooks of output (GDP), unemployment and inflation rates for the Turkish economy between the periods 2002-2016.

Fig. 5: Turkish Economy Social Welfare Indicators1

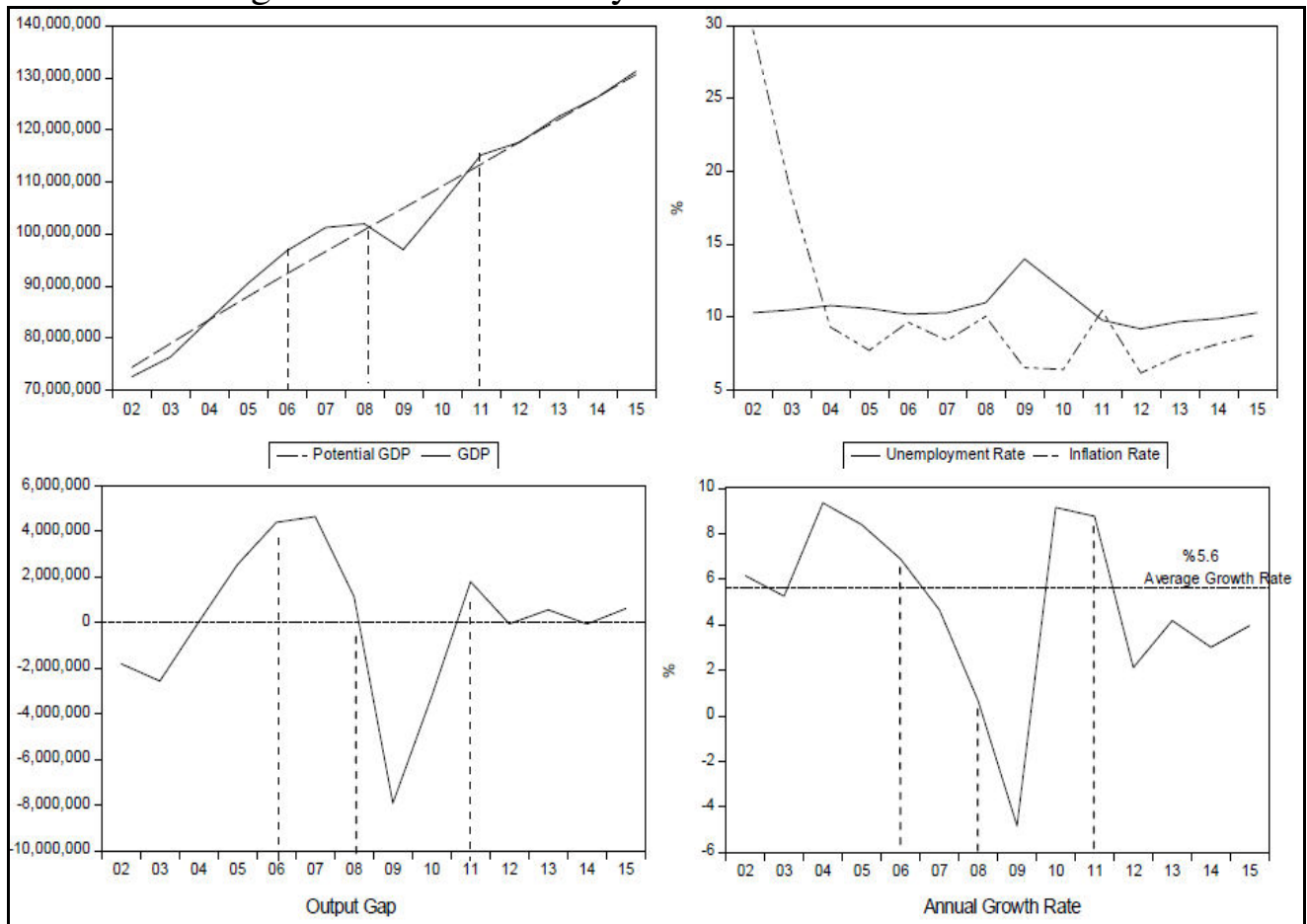

Source: Potential and Real GDP, Output Gap, Growth Rate and Inflation Rate data are given by CBRT, Unemployment Rate data are obtained from TURKSTAT, Average Growth Rate data from Ministry of Development databases.

Looking at Figure 5, first of all, an impressive appearance of growth figures after 2001 emerged in Turkey. The growth rate of output started to slow down after 2006, followed by negative global financial crisis in 2009 and the Turkish economy contracted. This contraction was a short-lived crisis, with output declining with the decline in impact in 2010-2011. However, the growth in output was well below the historical average of 92 years, which is below the average of $7.2 \%$ between 2002 and 2006, or even 5.6\%. Looking at 
the output gained by comparing the actual GDP with the potential GDP based on the Hodrick-Prescott filter, it appears that the output gap with the post2001 crisis and the 2009 global financial crisis has increased. However, as a result of policymakers' expansion policies aimed at increasing total demand, this output gap seems to have closed.

Looking at the unemployment rate, this rate is around $10 \%$. This rate does not change much even during periods of high growth and low labor force participation. Bakış (2015), pointed out the reason for this situation, inadequate public education, and various institutional factors that made the labor market very rigid. When the inflation rate is taken into consideration, it is seen that the inflation rate has fallen rapidly after 2001. It is seen that after 2005, the CBRT could not reach the inflation targets announced by the CBRT together with the open inflation targeting period.

An important example of the effectiveness of the policy cooperation in terms of the Turkish economy is the implicit inflation targeting period, which the CBRT imposes on monetary and inflation targeting anchors in 2002-2005. In this period, annual CPI inflation declined from 68 percent to 7.7 percent, while the Turkish economy reached an annual average growth rate of 7 percent. The steady growth rate also helped to reduce the volatility in output. In addition, exchange rates and volatility in financial markets have decreased and risk premium has also decreased. One of the important reasons for these positive developments in terms of social welfare is the co-operation of monetary and fiscal policies with inflation targets determined with the government. In this period, the fiscal policy maker, the government, has reduced the public debt stock by meeting primary surplus targets in fiscal discipline. Achieving inflation targets and ensuring fiscal discipline increased confidence in the monetary policies implemented (Bari, 2013).

An important example of policy inefficiency in terms of the Turkish economy is seen in the years 2012-2013 and later. In this period when the output was not gap, the monetary policy maker continued to revive the total demand with negative real interest rate. As a result of the fiscal policy maker's continued expansionism, overheating in the economy seems to cause inflation to go well above the target. In this case, it is seen in Figure- 4 that the monetary policy maker has increased interest rates in order to fight the increasing inflation since 2013. 


\section{PRISONER DILEMMA BETWEEN POLICY MAKERS}

The situation in which monetary and fiscal policy makers, based on their reaction functions, without co-operation, has already been shown in Figure 2. In this framework, the interaction between interest rates and budget deficit data, which represents the behavior of the monetary and fiscal policy maker for the Turkish economy and the years 2006-2016, is given in Figure 6.

Fig. 6: Interaction Between Policy Makers

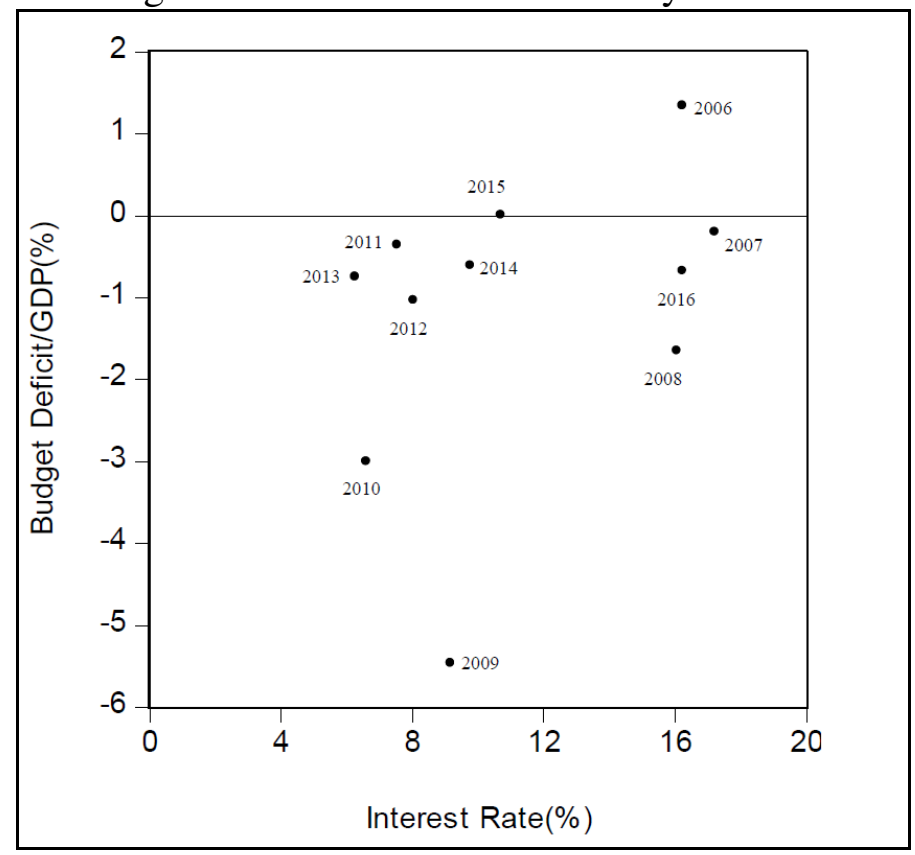

When we look at Figure 6, we see points similar to the Nash equilibrium in Figure 1, that is, points that no policy maker is happy about in terms of years. We can say that these points are years of high interest rates and budget deficits that both policy makers do not desire. So, for the policy makers of 2007, 2008, 2009 and 2016, the undesired equilibrium points, in other words, can be seen as years when policy makers fall into prisoner's dilemmas. These years are confronted by the fact that monetary and fiscal policymakers are making moves in line with independent policy objectives and therefore tend to develop distant policy preferences from their co-operation. As a matter of fact, if the years of 2007, 2008 and 2009 are considered to be the crisis period, it can be concluded that there is a coordination problem between the monetary and fiscal policy makers, especially in the crisis period.

\section{CONCLUSION}


Policies implemented by monetary and fiscal policy makers may have different objectives. The conflict of these objectives may reduce the social welfare of an individual country by affecting the macroeconomic policymaking process. This process is modeled within the framework of game theory, as policy makers are in strategic interaction in the process of macroeconomic policy formation. In these models, policies take into account the mutual strategic interaction between policy makers.

When the game is theoretically considered to be two mutually independent policy makers, a way that can be used to predict the outcome of this strategic interaction is that there are two policy makers, games with non-zero sum, and in particular Nash equilibrium. In this framework, the result of the game between policy makers, namely Nash equilibrium, (Contraction, Expansion) will be the strategy profile. In other words, the monetary policy maker is a contractionary policy, and the fiscal policy maker is applying an expansionary policy. The Nash equilibrium here reflects optimal behavior when non-coordinated between policy makers. However, for players, in this game has a better from this result. Policy makers' (Expansion, Contraction) strategy profile yields better results than Nash equilibrium. In the case of full coordination, policy makers will prefer this policy mix. The structure of game between policy makers is similar the prisoner's dilemma.

Considering the interaction between the monetary and fiscal policymakers in the Turkish economy, it can be said that the prisoner's dilemma were faced with especially in 2007, 2008, 2009 and 2016. This can be said to be the reason why the monetary policy maker continued to have high interest policies in these periods, as the fiscal policy maker has shown an expansionary stance since 2006 and has not given up the expansionist attitude despite the diminishing effect of the crisis.

\section{REFERENCE}

1. Alp, H., Gürkaynak, R., Kara, H., Keleş, G., \& Orak, M. 2010. Türkiye'de piyasa göstergelerinden para politikası beklentilerinin ölçülmesi. İktisat Işletme ve Finans, 25(295), 21-45.

2. Bakış, O. 2015. Türkiye İşü̈cü Piyasasında Güncel Eğilimler. İktisat İsletme ve Finans, 30(351), 73-110.

3. Bari, B. 2013. Yeni Keynesyen Modelde Optimum Para Politikast: Türkiye İçin Dinamik Stokastik Genel Denge Modeli Tahmini. Yayınlanmamış Doktora Tezi, Anadolu Üniversitesi Sosyal Bilimler Enstitüsü, Eskişehir.

4. Blinder, A. S. 1982. Issues in the coordination of monetary and fiscal policy. Kansas City: Federal Reserve Bank of Kansas City. 
5. Davig, T., \& Gurkaynak, R. S. 2015. Is optimal monetary policy always optimal? Research Working Pepers. Kansas City: Federal Reserve Bank of Kansas City.

6. Gürkaynak, R. S., Kantur, Z., Taş, M. A., \& Yıldırım, S. 2015. Monetary policy in Turkey after Central Bank independence.

7. Nordhaus, W. D., Schultze, C. L., \& Fischer, S. 1994. Policy games: coordination and independence in monetary and fiscal policies. Brookings Papers on Economic Activity, 1994(2), 139-216.

8. Telatar, Erdinç, Funda Erdoğan. 1997. Para Politikası Oyununda İnandirıcılık, Ankara: Hacettepe Üniv. İ.İ.B.F. Yayınları, No:25.

9. EVDS, 2017. Eletronic Data Delivery System. [online] Available at: $<$ https://evds2.tcmb.gov.tr/> [Accessed 10.12.2017.]

10. Ministry of Development Republic of Turkey, 2017. Main Economic Indicators. [online] Available at: <http://www.mod.gov.tr/Pages/MainEconomicIndicators.aspx> [Accessed 11.12.2017.]

11. Republic of Turkey Prime Ministry Undersecretariat of Treasury, 2017. Statistics. [online] Available at: <https://www.treasury.gov.tr/public-finance-statistics> [Accessed 11.12.2017.]

12. Turkish Lira Reference Interest Rate, 2017. Rate and Statistics. [online] Available at: 〈http://www.trlibor.org/english/veriler.aspx> [Accessed 11.12.2017.]

13. Turkish Statistical Institute, 2017. Main Statistics [online] Available at: <http://www.turkstat.gov.tr/> [Accessed 10.12.2017.]

Received: 14 December, 2017

Accepted: 23 December, 2017 